\title{
REAKSI PASAR TERHADAP PENGUMUMAN RIGHT ISSUE DI BURSA EFEK INDONESIA TAHUN 2013-2017
}

\author{
John Santo 1 \\ Henny Rahyuda ${ }^{2}$ \\ ${ }^{1,2}$ Fakultas Ekonomi dan Bisnis Universitas Udayana (Unud), Bali,Indonesia \\ e-mail: johnsantoe25@gmail.com
}

\begin{abstract}
ABSTRAK
Right issue adalah salah satu corporate action yang dapat dilakukan oleh perusahaan. Right issue berupa hak yang diberikan kepada semua pemegang saham untuk membeli saham dengan harga tertentu, biasanya di bawah harga pasar. Penelitian ini bertujuan untuk mengetahui reaksi pasar yang ditimbulkan oleh pengumuman right issue, dan mampu mengetahui perbedaan abnormal return sebelum dan sesudah pengumuman right issue. Penelitian ini dilakukan di Bursa Efek Indonesia dengan jumlah peristiwa right issue sebanyak 66 peristiwa. Metode pengumpulan data yang dilakukan dengan metode observasi non-partisipan. Berdasarkan hasil penelitian yang dilakukan bahwa tidak terdapat abnormal return yang signifikan sebelum, saat, dan sesudah pengumuman right issue. hal ini berarti pengumuman right issue tidak memiliki kandungan informasi yang dapat membuat pasar bereaksi dengan memberikan abnormal return. Pengujian dengan metodologi nonparametrik memberikan kesimpulan tidak terdapat perbedaan abnormal return sebelum dan sesudah pengumuman right issue.
\end{abstract}

Kata kunci: corporate action, right issue, abnormal return, efisiensi pasar

\begin{abstract}
Right issue is one of the corporate actions that can be carried out by a company. This study aims to determine the market reaction caused by the announcement of the rights issue, and is able to know the difference in abnormal returns before and after the announcement of the rights issue. This research was conducted at the Indonesia Stock Exchange with a total of 66 rights issues. Data collection methods are carried out using non-participant observation methods. Based on the results of research that there were no significant abnormal returns before, during, and after the announcement of the rights issue. this means that the announcement of the rights issue does not contain information that can make the market react by giving abnormal returns. Testing with non-parametric methodology tool provides a conclusion that there is no difference in abnormal returns before and after the announcement of the rights issue.
\end{abstract}

Keywords: corporate action, right issue, abnormal return, market efficiency 


\section{PENDAHULUAN}

Pasar modal tercipta dalam suatu negara agar dapat menjadi penggerak perekonomian. Pasar modal menjalankan fungsi ekonomi, yaitu dengan mengalokasikan dana secara efisien dari pihak yang memiliki dana kepada pihak yang membutuhkan dana. Investor dan emiten dihubungkan oleh pasar modal yang menjadi perantara terjadinya transaksi menghimpun dana, sehingga pasar modal adalah pertemuan antara pihak yang memiliki kelebihan dana dengan pihak yang membutuhkan dana dengan cara memperjualbelikan sekuritas (Tandelilin, 2010:26).

Investor melakukan sejumlah investasi untuk memperoleh keuntungan. Definisi investasi menurut Tandelilin (2010:3) adalah komitmen atas sejumlah dana atau sumber daya lainnya yang dilakukan pada saat ini, dengan tujuan memperoleh sejumlah keuntungan di masa mendatang. Dalam berinvestasi seseorang tentu akan dihadapkan pada suatu risiko yang dinamakan risiko berinvestasi, sehingga dalam melakukan investasi seseorang harus selalu mempertimbangkan tingkat risiko. Menurut Tandelilin (2010:102) risiko investasi bisa diartikan sebagai kemungkinan perbedaan antara actual return yang diterima dengan expected return. Actual return pada penelitian ini dihitung menggunakan data closing price. Expected return pada penelitian ini dihitung menggunakan data harga pasar yang tercermin melalui indeks. Abnormal return merupakan selisih antara hasil yang didapatkan investor (actual return) dengan tingkat keuntungan diharapkan (expected return) (Jogiyanto, 2015:580). 
Perkembangan aktivitas pasar modal yang pesat akan membawa perubahan besar pada tuntutan kualitas informasi. Kualitas informasi penting dalam pasar modal karena akan mempengaruhi keputusan investor yang menerima informasi tersebut. Dalam pasar modal yang efisien semua informasi baru dengan cepat dan secara lengkap tercermin dalam harga sekuritas (Tandelilin, 2010:219). Semakin cepat informasi tercermin dalam harga sekuritas, semakin efisien pasar modal yang bersangkutan. Pasar efisien bentuk setengah kuat menyatakan bahwa hargaharga saham menggambarkan informasi yang dipublikasikan. Pasar efisien bentuk kuat menyatakan bahwa harga yang terjadi mencerminkan semua informasi yang ada, baik informasi publik (public information) maupun informasi pribadi (private information). Pasar efisien dalam bentuk setengah kuat dapat diuji melalui studi peristiwa (event study).

Informasi yang diterima dipasar dapat berupa berita baik atau berita buruk. Reaksi adalah aktivitas yang timbul akibat adanya suatu peristiwa. Hipotesis pasar efisien memprediksi bahwa pasar akan memberikan reaksi positif untuk berita baik, dan reaksi negatif untuk berita buruk. Reaksi pasar tersebut tercermin dari abnormal return positif (good news) dan abnormal return negatif (bad news) (Tandelilin, 2010:565). Jika pasar bereaksi karena informasi pengumuman tersebut, hal ini bukan berarti bahwa pasar bereaksi karena informasi pengumuman tersebut, akan tetapi bereaksi karena mengetahui prospek perusahaan di masa depan yang disinyalkan melalui pengumuman (Lianawati, 2015). 
Suatu langkah perusahaan yang dapat diambil dalam rangka memberikan informasi yang nantinya dapat menarik investor untuk melakukan transaksi di pasar modal disebut dengan corporate action. Adanya aktivitas corporate action akan menimbulkan reaksi yang berbeda-beda. Reaksi ini tercermin dari adanya abnormal return. Tujuan perusahaan melakukan corporate action adalah untuk meningkatkan kinerja yang bersifat jangka pendek maupun jangka panjang. Beberapa bentuk corporate action yang dilakukan para emiten adalah right issue, saham bonus, pengumuman dividen, stock split, merger dan akuisisi.

Right issue berupa penerbitan saham baru yang dijual kepada pemegang saham yang namanya masih terdaftar dalam perusahaan melalui penawaran umum terbatas dalam rangka penambahan modal perusahaan. Tujuan perusahaan melakukan right issue adalah untuk menghemat biaya emisi, menambah atau memperkuat modal perusahaan dan menambah jumlah saham yang beredar (Fahmi, 2014:119). Pemegang saham dapat memanfaatkan right issue untuk mempertahankan proporsi kepemilikan sahamnya dalam perusahaan emiten. Right issue tidak memaksa pemegang saham lama untuk membelinya. Pemegang saham lama dapat memilih untuk tidak menggunakan right issue, tetapi menjual right issue tersebut kepada pihak lain dan mendapat keuntungan.

Indeks Harga Saham Gabungan (IHSG) adalah indikator atau cerminan pergerakan harga saham seluruh perusahaan yang tercatat di Bursa Efek Indonesia (Pardede, 2018). Indeks merupakan salah satu pedoman untuk melakukan investasi di pasar modal khususnya saham. IHSG digunakan untuk mengetahui bagaimana kegiatan ekonomi bergerak, banyak orang akan melihatnya dari sisi 
indeks yang dicapai pada saat itu. IHSG menggunakan semua perusahaan tercatat sebagai komponen perhitungan indeks. berikut perkembangan IHSG di Indonesia tahun 2013-2017.

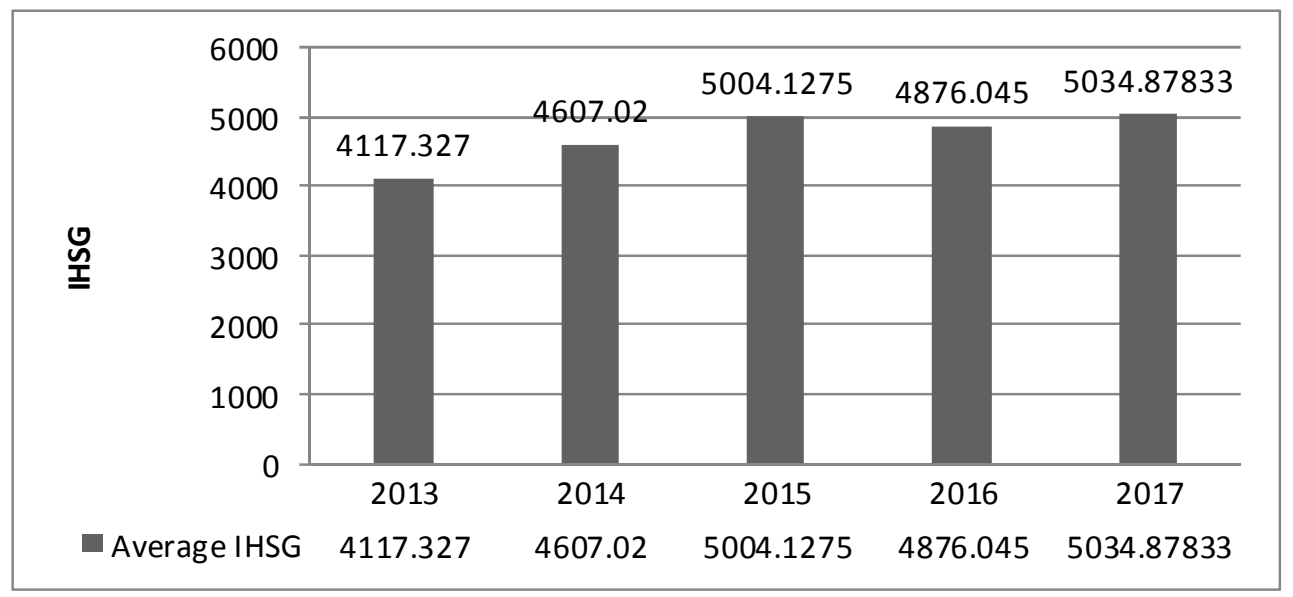

Gambar 1. Perkembangan Indeks Harga Saham Gabungan di Indonesia Tahun 2013 - 2017

Sumber: Badan Pusat Statistik, 2018

Berdasarkan gambar di atas dapat dilihat pergerakan harga saham secara keseluruhan perusahaan-perusahaan yang terdaftar di Bursa Efek Indonesia. Melalui gambar diatas, dapat diketahui rata-rata indeks harga saham seluruh perusahaan yang terdaftar di bursa pada periode 2013-2017. Gambar diatas menunjukkan terjadi fluktuasi terhadap rata-rata IHSG pada periode 2013-2017. Fluktuasi pada harga saham di pasar terjadi karena banyak faktor, salah satunya adalah akibat dari corporate action yang dilakukan oleh emiten. Perusahaan melakukan right issue dengan harapan pelaku pasar akan merespon dan memberikan abnormal return positif.

Penelitian yang dilakukan oleh Kumar et al. (2010), Miglani (2011), Cotterell (2011), Malhotra et al. (2012), Massa et al. (2013), Otieno dan Ochieng (2015), Edirisinghe dan Nimal (2015), Kendirli dan Elmali (2016), dan Khoso et 
al. (2016), menyimpulkan bahwa pelaku pasar mempunyai respon terhadap pengumuman right issue, yang ditunjukkan dengan terjadi abnormal return saham (baik positif maupun negatif) di antara periode sebelum dan sesudah tanggal pengumuman right issue. Hasil penelitian yang berlawanan ditemukan oleh Shahid et al. (2010), Dewi dan Putra (2013), Nurmala dan Salmah (2015), menyimpulkan bahwa tidak terjadi abnormal return saham antara periode sebelum dan sesudah pengumuman right issue. Hal ini berarti pasar tidak merespon terhadap pengumuman right issue.

Penelitian yang dilakukan oleh Miglani (2011), Suresha dan Naidu (2012), Agarwal dan Mohanty (2012), Epriyeni dan Kharlina (2013), Ahkam dan Mostafa (2013), dan Rohit et al. (2016), menyimpulkan bahwa terdapat abnormal return saham pada saat pengumuman right issue. Hasil penelitian yang berlawanan ditemukan oleh Bharath dan Shankar (2012), Bashir (2013), menyimpulkan bahwa tidak terjadi abnormal return pada saat pengumuman right issue. Hal ini berarti tidak terdapat reaksi pasar terhadap pengumuman right issue.

Penelitian yang dilakukan oleh Epriyeni dan Kharlina (2013), menyimpulkan bahwa terdapat perbedaan abnormal return saham antara periode sebelum dan sesudah pengumuman right issue. Hasil penelitian yang berlawanan ditemukan oleh Pratama dan Sudhiarta (2013), Jayanti dan Kristanti (2014), Ardiana dan Susanti (2014), Hermawan dan Wijayanto (2015), menyimpulkan bahwa tidak terdapat perbedaan abnormal return saham antara periode sebelum dan sesudah pengumman right issue. 
Perbedaan hasil penelitian diatas membuat peneliti melihat ada sebuah peluang untuk meneliti kembali mengenai reaksi pasar terhadap pengumuman right issue di Bursa Efek Indonesia. Penelitian ini akan dilakukan di Bursa Efek Indonesia, pada periode 2013-2017. Dilakukan pada seluruh perusahaan yang terdaftar di Bursa Efek Indonesia. Penelitian ini menggunakan event study untuk melakukan pengamatan pergerakan abnormal return dari hari ke hari menggunakan model sesuaian-pasar (market-adjusted model). Periode pengamatan selama 11 hari (5 hari sebelum dan 5 hari setelah tanggal pengumuman right issue) (Lianawati, 2015).

Tujuan dari penelitian ini adalah untuk mengetahui apakah terjadi abnormal return pada saat sebelum dan sesudah pengumuman right issue, untuk mengetahui apakah terjadi abnormal return pada saat pengumuman right issue, dan untuk mengetahui apakah terdapat perbedaan abnormal return sebelum dan sesudah pengumuman right issue. Adapun mamnfaat dari penelitian ini secara teoritis, penelitian ini diharapkan dapat memberikan sumbangan bukti empiris mengenai reaksi pasar terhadap pengumuman right issue di Bursa Efek Indonesia pada tahun 2013-2017. Penelitian ini juga diharapkan mampu memberikan manfaat bagi perusahaan emiten, sebagai bahan pertimbangan dalam membuat kebijakan keuangan keputusan investasi di masa mendatang. Bagi investor, sebagai bahan pertimbangan dalam menetapkan keputusan invetasi yang tepat sehingga dapat mengoptimalkan keuntungan dan meminimalkan risiko.

Kerangka konsep ini yang disusun dalam penelitian ini menunjukkan bahwa corporate action dilakukan perusahaan dalam bentuk right issue dan diharapkan 
akan memberikan abnormal return. Abnormal return pada penelitian ini dinilai dengan melihat abnormal return pada saat sebelum dan sesudah pengumuman right issue. Kemudian akan dilakukan uji normalitas untuk melihat data yang digunakan berdistribusi normal. Jika data yang digunakan berdistribusi normal, maka akan dilakukan uji parametrik dengan alat analisis one sample t-test dan paired sample t-test. Jika data tidak berdistribusi normal, maka akan dilakukan uji non-parametrik dengan alat analisis wilcoxon signed-rank test. Sehingga akan didapatkan hasil penelitian.

Semakin cepat informasi tercermin dalam harga sekuritas, semakin efisien pasar modal yang bersangkutan. Informasi yang ada tersebut meliputi semua informasi baik informasi dari masa lampau maupun informasi saat ini dan informasi yang dinyatakan dalam pendapat atau opini rasional yang beredar di pasar. Informasi ini dapat mempengaruhi harga saham. Konsep pasar efisien ini mengindikasikan terdapat proses penyesuaian harga suatu sekuritas menuju harga keseimbangan yang baru (Cotterell, 2011).

Studi peristiwa (event study) merupakan metolodogi yang ditemukan oleh Eugene Fama pada tahun 1969, tujuannya untuk mengamati reaksi pasar terhadap suatu peristiwa (event) yang informasinya dipublikasikan sebagai suatu pengumuman. Event study dapat digunakan untuk menguji kandungan informasi (information content) dari suatu pengumuman dan dapat juga digunakan untuk menguji efisiensi pasar bentuk setengah kuat (Jogiyanto, 2015:536).

Pengujian kandungan informasi dan pengujian efisiensi pasar bentuk setengah kuat merupakan dua pengujian yang berbeda. Pengujian kandungan 
informasi dimaksudkan untuk mengetahui information content, maka diharapkan pasar akan bereaksi pada waktu pengumuman tersebut diterima oleh pasar. Reaksi pasar dapat diukur dengan menggunakan return sebagai nilai perubahan harga atau dengan menggunakan abnormal return. Jika menggunakan abnormal return, maka dapat dikatakan bahwa suatu pengumuman yang mempunyai kandungan informasi akan memberikan abnormal return kepada pasar. Sebaliknya yang tidak mengandung informasi tidak memberikan abnormal return kepada pasar.

Pengujian kandungan informasi hanya menguji reaksi dari pasar, tetapi tidak menguji seberapa cepat pasar itu bereaksi. Jika pengujian melibatkan kecepatan reaksi pasar untuk menyerap informasi yang diumumkan, maka pengujian ini merupakan pengujian efisiensi pasar secara informasi (information efficient market) bentuk setengah kuat. Pasar dikatakan efisien bentuk setengah kuat jika investor bereaksi cepat (quickly) menyerap abnormal return untuk menuju ke harga keseimbangan yang baru. Jika investor menyerap abnormal return dengan lambat, maka pasar dikatakan tidak efisien bentuk setengah kuat secara informasi.

Perusahaan yang sudah terdaftar di pasar modal ada kalanya membutuhkan tambahan dana, jika sumber internal dan pinjaman dari bank dianggap kurang memadai atau menguntungkan. Alternatif untuk memperoleh tambahan dana adalah dengan menawarkan kepada pegang saham lama untuk membeli saham baru, bertujuan agar pemegang saham lama berminat untuk membeli saham baru tersebut, maka perusahaan akan menawarkan saham baru itu dengan harga yang (jauh) lebih murah dari harga saham saat ini. Right issue merupakan salah satu 
cara yang dilakukan oleh perusahaan yang telah terdaftar (listed) di Bursa Efek untuk memperoleh dana (Fahmi, 2014:116-117).

Fahmi (2014:117) berpendapat para manajer keuangan perlu menentukan struktur pendanaan dalam upaya menetapkan apakah kebutuhan dana perusahaan dipenuhi dengan modal sendiri atau dipenuhi dengan modal asing dan sumbersumber dana yang diperlukan untuk melakukan investasi dapat berasal dari dalam perusahaan (internal fund) dan dari luar perusahaan (eksternal fund). Dari pendapatan tersebut dapat dipahami dengan melakukan right issue perusahan menjadi lebih baik dalam arti pendanaan yang diperoleh dari hasil right issue yang berasal dari pemilik saham lama akan memudahkan perusahaan untuk tidak berurusan dengan pihak eksternal seperti berutang atau mengajukan pinjaman pada bank.

Pengertian right issue menurut Sutedi (2012:90) merupakan pengeluaran saham baru dalam rangka penambahan modal perusahaan, namun terlebih dahulu ditawarkan kepada pemegang saham saat ini (existing shareholder). Right issue berupa penerbitan saham baru yang dijual kepada pemegang saham yang namanya masih terdaftar dalam perusahaan melalui penawaran umum terbatas dalam rangka penambahan modal perusahaan (Fahmi, 2014:119). Menurut Tandelilin (2010:3), right issue pada hakikatnya merupakan hak memesan saham terlebih dahulu yang diberikan kepada pemodal saat ini untuk membeli saham baru yang dikeluarkan emiten dalam rangka menghimpun dana. Right issue diberikan kepada pemegang saham lama guna untuk menjaga proporsi kepemilikannya dalam suatu perusahaan sehubungan dengan pengeluaran saham baru. 
Jadi, menurut pengertian diatas right issue adalah hak memesan saham yang dikeluarkan oleh perusahaan, terlebih dahulu ditawarkan kepada pemegang saham lama untuk dapat membeli saham baru dengan harga tertentu, dengan tujuan untuk menambah modal dan memberikan proporsi kepemilikan saham yang tetap bagi investor. Ketika tambahan saham baru dijual kepada publik, proporsi kepemilikan dari pemegang saham lama dapat mengalami dilusi (berkurangnya proporsi kepemilikan saham investor). Karena alasan inilah, ketika perusahaan hendak menawarkan saham atau sekuritas tambahan, banyak perusahaan memberikan kesempatan pertama kepada pemegang saham lama untuk memesan terlebih dahulu saham tersebut. Hak ini disebut preemtive yang diberikan kepada pemegang saham lama dengan alasan melindungi proporsi kepemilikan pemegang saham lama terhadap perusahaan.

Teori sinyal mengindikasikan bahwa pengumuman right issue dianggap sebagai suatu sinyal oleh investor yang dapat mempengaruhi nilai saham mereka. Dengan adanya sinyal dari perusahaan menyebabkan investor menentukan investasi yang tepat (Nugraha dan Daud, 2013). Penelitian mengenai pengujian reaksi pasar dapat diukur dengan melihat abnormal return. Abnormal return adalah dari selisih actual return dengan expected return. Expected return biasanya disebut juga dengan return normal (return yang diharapkan investor). Reaksi dapat dilihat dari terdapatnya abnormal return di sekitar tanggal pengumuman. Reaksi pasar tersebut tercermin dari abnormal return positif (good news) dan abnormal return negatif (bad news) (Tandelilin, 2010:565). 
John Santo dan Henny Rahyuda, Reaksi Pasar Terhadap ...

Berdasarkan penjelasan mengenai signaling theory dapat disimpulkan bahwa seharusnya terjadi reaksi pasar saat perusahaan memberikan sinyal kepada publik. Sinyal yang dimaksud dalam hal ini ialah right issue. Berarti pasar seharusnya bereaksi atas pengumuman right issue. Hal ini semakin diperkuat dengan hasil-hasil empiris yang ditemukan oleh peneliti terdahulu. Miglani (2011) menemukan bahwa nilai saham perusahaan meningkat secara signifikan sebelum dan sesudah pengumuman right issue. Otieno dan Ochieng (2015) menemukan bahwa terjadi abnormal return negatif sebelum dan sesudah pengumuman right issue. Berdasarkan penjelasan tersebut, maka hipotesis dalam penelitian ini dapat dirumuskan sebagai berikut:

$\mathrm{H}_{1}$ : Terjadi abnormal return sebelum dan sesudah pengumuman right issue.

Agarwal dan Mohanty (2012) dalam penelitiannya menemukan hubungan yang sangat kuat dan positif mengenai abnormal return yang terjadi pada saat pengumuman right issue. Didukung dengan pengamatan yang dilakukan Rohit et al. (2016) menemukan bahwa average abnormal return yang positif pada hari pengumuman. Lianawati (2015) menemukan abnormal return yang signifikan bernilai negatif pada saat pengumuman right issue. Penelitian yang dilakukan peneliti terdahulu menunjukkan bahwa terdapat reaksi yang positif maupun negatif pada hari pengumuman right issue. Berdasarkan penjelasan tersebut, maka hipotesis dalam penelitian ini dapat dirumuskan sebagai berikut:

$\mathrm{H}_{2}$ : Terjadi abnormal return pada saat pengumuman right issue.

Penelitian yang dilakukan oleh Epriyeni dan Kharlina (2013) menyatakan bahwa terdapat perbedaan abnormal return sebelum, saat dan setelah 
pengumuman right issue. Hasil penelitian ini menunjukan pengumuman right issue berpengaruh terhadap abnormal return. Didukung oleh penelitian yang dilakukan oleh Ahkam dan Mostafa (2013), Suresha dan Naidu (2012) menyatakan bahwa terdapat perbedaan abnormal return yang signifikan selama masa pengumuman right issue. Berdasarkan penjelasan tersebut, maka hipotesis dalam penelitian ini dapat dirumuskan sebagai berikut:

$\mathrm{H}_{3}$ : Terdapat perbedaan abnormal return sebelum dan sesudah pengumuman right issue.

\section{METODE PENELITIAN}

Penelitian ini akan melakukan analisis terhadap laporan keuangan pada perusahaan go public di Bursa Efek Indonesia yang melakukan right issue pada periode 2013-2017. Penelitian ini lebih terkonsentrasi pada pengumuman right issue yang dikeluarkan oleh perusahaan go public yang tercatat di Bursa Efek Indonesia. Data diperoleh dari laporan historis yang dikeluarkan Bursa Efek Indonesia periode 2013-2017 yang di akses pada website IDX. Objek penelitian ini adalah perusahaan go public yang melakukan right issue dan mendapatkan abnormal return pada periode 2013-2017 di Bursa Efek Indonesia. Penelitian ini menggunakan data dalam jangka waktu selama lima tahun agar dapat mencerminkan kondisi kinerja keuangan perusahaan dan bersifat up to date.

Adapun definisi masing- masing operasional variabel yakni untuk return saham atau actual return adalah sejumlah tingkat keuntungan yang diharapkan oleh investor melalui investasi saham. Rumus menghitung actual return adalah sebagai berikut (Jogiyanto, 2015:207): 


$$
R_{I, t}=\underline{\mathrm{P}}_{i t}-\mathrm{P}_{\mathrm{it}-1}
$$

Keterangan:

$R_{i t}=$ Return atau actual return saham perusahaan I pada waktu

$P_{i, t}=$ Harga saham perusahaan i pada waktu t

$P_{i, t-l}=$ Harga saham perusahaan i sebelum waktu t

Return pasar adalah pendapatan portofolio pasar yang diperoleh jika semua saham di pasar dikuasai dalam proporsi sama. Rumus menghitung return pasar harian adalah sebagai berikut (Jogiyanto, 2015:207):

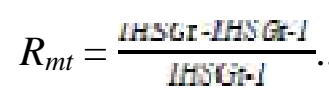

Keterangan:

$R_{m t} \quad=$ Return pasar pada waktu ke-t

$I H S G_{t}=$ Indeks Harga Saham Gabungan hari ke-t

$I H S G_{t-1}=$ Indeks Harga Saham Gabungan hari ke- ${ }_{\mathrm{t}-1}$

Expected return adalah return yang diharapkan akan diperoleh investor di masa mendatang. Model ini tidak memerlukan periode estimasi sehingga penelitian menjadi tidak bias. Rumus return ekspektasi ialah sebagai berikut, (Tandelilin, 2010:574):

$$
\mathrm{E}\left(\mathrm{R}_{\mathrm{it}}\right)=\mathrm{R}_{\mathrm{i}, \mathrm{t}}-\mathrm{R}_{\mathrm{mt}}
$$

Keterangan:

$$
\begin{array}{ll}
\mathrm{E}\left(\mathrm{R}_{\mathrm{it}}\right) & =\text { Expected return } \\
R_{i, t} & =\text { Return sesungguhnya yang terjadi untuk sekuritas ke-I } \\
& \text { pada periode peristiwa ke-t } \\
R_{m t} & =\text { Return } \text { Pasar harian }
\end{array}
$$

Abnormal return merupakan selisih antara hasil yang didapatkan dari investor (actual return) dengan tingkat keuntungan diharapkan (expected return). Menghitung abnormal return untuk masing-masing emiten (Jogiyanto, 2015:580): 
$\mathrm{RTN}_{\mathrm{i}, \mathrm{t}}=R_{i, t}-\mathrm{E}\left[\mathrm{R}_{\mathrm{i}, \mathrm{t}}\right]$

Keterangan:

$\mathrm{RTN}_{\mathrm{i}, \mathrm{t}}=$ return tak nomal (abnormal return) sekuritas ke-i pada periode peristiwa ke-t

$R_{i, t} \quad=$ return realisasian yang terjadi untuk sekuritas ke-i pada periode peristiwa ke-t

$\mathrm{E}\left[R_{i, t}\right] \quad=$ return ekspektasian sekuritas ke-i untuk periode peistiwa ke-t

Data kuantitatif yang digunakan dalam penelitian ini adalah return saham, harga saham dan indeks harga saham gabungan (IHSG) perusahaan go public di Bursa Efek Indonesia (BEI) pada periode 2013-2017. Data kualitatif merupakan data yang berbentuk kata, kalimat, skema, dan gambar (Sugiyono, 2012:7). Data kualitatif yang digunakan dalam penelitian ini adalah gambaran umum perusahaan. Sumber data yang digunakan dalam penelitian ini adalah data sekunder. Data sekunder adalah data yang diperlukan untuk mendukung hasil penelitian berasal dari literatur, artikel dan berbagai sumber lainnya yang berhubungan dengan penelitian (Sugiyono 2012:137). Data sekunder yang digunakan dalam penelitian ini berasal dari website $I D X$.

Populasi pada penelitian ini yaitu seluruh perusahaan go public yang melakukan corporate action yaitu right issue dan terdaftar di Bursa Efek Indonesia (BEI) pada periode 2013-2017. Sampel pada penelitian ini diambil dari semua populasi yaitu sebanyak 66 perusahaan. Metode pengumpulan data dalam penelitian ini dilakukan dengan cara pengumpulan data berupa metode observasi non-partisipan. Pengumpulan data dalam penelitian ini, melakukan pengamatan dan mencatat serta mempelajari uraian-uraian dari buku, jurnal, dan skripsi. 
Melakukan akses ke Bursa Efek Indonesia (BEI). Data tersebut dapat diperoleh dalam bentuk laporan historis di website IDX.

Penelitian ini menggunakan uji asumsi klasik terlebih dahulu kemudian dilakukan Uji One sample t-test atau uji t satu sampel, One sample t-test ini digunakan untuk menguji signifikansi abnormal return di seputar tanggal pengumuman right issue, sebelum dan sesudah pengumuman right issue. Data yang digunakan diolah dengan program SPSS. Setelah itu dilakukan uji Paired Sample T-Test digunakan untuk menguji bahwa ada atau tidaknya perbedaan antara dua variabel.

\section{HASIL DAN PEMBAHASAN}

Pemerintah Republik Indonesia mengaktifkan kembali pasar modal pada tahun 1977. Bursa Efek Jakarta dijalankan dibawah BAPEPAM (Badan Pelaksana Pasar Modal). Pengaktifan kembali pasar modal ini juga ditandai dengan go public PT Semen Cibinong sebagai emiten pertama. Beberapa tahun kemudian pasar modal mengalami pertumbuhan seiring dengan berbagai insentif dan regulasi yang dikeluarkan pemerintah.

Tahun 2001 Bursa Efek Jakarta mulai menerapkan perdagangan jarak jauh (remote trading), sebagai upaya meningkatkan akses pasar, efisiensi pasar, kecepatan dan frekuensi perdagangan. Tahun 2007 menjadi titik penting dalam sejarah perkembagan pasar modal Indonesia. Berdasarkan persetujuan para pemegang saham kedua bursa, Bursa Efek Surabaya (BES) digabungkan ke dalam Bursa Efek Jakarta (BEJ) yang kemudian menjadi Bursa Efek Indonesia (BEI) dengan meningkatkan peran pasar modal dalam perekonomian Indonesia. Pada 
tahun 2008, pasar modal terkena imbas krisis keuangan dunia menyebabkan tanggal 8-10 Oktober 2008 terjadi penghentian sementara perdagangan di Bursa Efek Indonesia. Indeks Harga Saham Gabungan (IHSG) yang sempat menyentuh titik tertinggi 2.830,26 pada tanggal 9 Januari 2008, terperosok jauh hingga 1.111,39 pada tanggal 28 Oktober 2008 sebelum ditutup pada level 1.355,41 pada akhir tahun 2008. Kemerosotan tersebut dipulihkan kembali dengan pertumbuhan 86,98 persen pada tahun 2009 46,13 persen pada tahun 2010 .

Perusahaan yang melakukan right issue di Bursa Efek Indonesia pada periode 2013-2017 terdiri dari berbagai jenis sektor perusahaan, dalam penelitian ini menggunakan sembilan sektor perusahaan. Sektor perusahaan tersebut meliputi: 1). Keuangan, sektor ini meliputi lembaga pembiayaan, bank, perusahaan efek, dan asuransi; 2). Infrastruktur, Utilitas, dan Transportasi, sektor ini meliputi energi, jalan tol, pelabuhan, bandara dan sejenisnya, telekomunikasi, transportasi, konstruksi non bangunan; 3). Perdagangan, Jasa, dan Investasi, sektor ini meliputi perdagangan besar barang produksi, perdagangan eceran, restoran, hotel dan pariwisata, advertising, printing dan media, jasa komputer dan perangkatnya, perusahaan investasi; 4). Properti dan Real Estat, sektor ini meliputi properti dan real estat, serta kontruksi bangunan; 5). Industri Dasar dan Kimia, sektor ini meliputi semen, keramik, porselen dan kaca, logam dan sejenisnya, kimia, plastik dan kemasan, pakan ternak, kayu dan pengolahannya, pulp dan kertas; 6). Aneka Industri, sektor ini meliputi dan komponennya, tekstil dan garmen, alas kaki, kabel, elektronika; 7). Pertambangan, sektor ini meliputi pertambangan batu bara, pertambangan minyak dan gas bumi, pertambangan 
logam dan mineral lainnya, pertambangan batu-batuan; 8). Pertanian, sektor ini adalah penghasil bahan baku yang diperoleh dari hasil bumi berupa perkebunan, peternakan dan perikanan; 9). Industri Barang Konsumsi, sektor ini meliputi makanan dan minuman, rokok, farmasi, kosmetik, dan barang keperluan rumah tangga, peralatan rumah tangga. Dari sembilan sektor perusahaan di Bursa Efek Indonesia terdapat 66 perusahaan yang melakukan right issue.

Hasil analisis abnormal return secara statistik, dapat dilihat pada Tabel 1. di sebagai berikut.

\section{Tabel 1.}

Sebaran Data Abnormal Return Di Sekitar Peristiwa Right Issue (Rupiah)

\begin{tabular}{clcccc}
\hline $\begin{array}{c}\text { Periode } \\
\text { Pengamatan }\end{array}$ & N & Minimum & Maximum & Mean & Std. Deviation \\
\hline H-5 & 66 & -.13 & .26 & .0034 & .05877 \\
H-4 & 66 & -.12 & .24 & -.0043 & .05371 \\
H-3 & 66 & -.26 & .13 & -.0054 & .05068 \\
H-2 & 66 & -.25 & .13 & -.0080 & .05124 \\
H-1 & 66 & -.13 & .36 & .0035 & .05888 \\
H & 66 & -.08 & .32 & .0081 & .06787 \\
H+1 & 66 & -.12 & .38 & .0116 & .07208 \\
H+2 & 66 & -.17 & .24 & -.0060 & .06368 \\
H+3 & 66 & -.13 & .24 & -.0086 & .04245 \\
H+4 & 66 & -.14 & .09 & -.0086 & .04079 \\
H+5 & 66 & -.10 & .21 & .0039 & .03683 \\
\hline \multicolumn{2}{c}{ Sumber: Data diolah, 2018 } & & & &
\end{tabular}

Tabel 1 menjelaskan nilai minimum, maksimum, rata-rata dan standar deviasi pada abnormal return sebelum dan sesudah peristiwa right issue. Pada H5 nilai minimum sebesar -0.13 diperoleh perusahaan Marga Abhinaya Abadi Tbk. Nilai maksimum sebesar 0.26 diperoleh perusahaan Anugerah Kagum Karya Utama Tbk. Rata-rata abnormal return $\mathrm{H}-5$ bernilai positif sebesar 0.0034 dan 
standar deviasi sebesar 0.05877. Pada H-4 nilai minimum sebesar -0.12 diperoleh perusahaan Centratama Telekomunikasi Indonesia Tbk. Nilai maksimum sebesar 0.24 diperoleh perusahaan Anugerah Kagum Karya Utama Tbk. Rata-rata abnormal return $\mathrm{H}-4$ bernilai negatif sebesar -0.0043 dan standar deviasi sebesar 0.05371. Pada H-3 nilai minimum sebesar -0.26 diperoleh perusahaan Marga Abhinaya Abadi Tbk. Nilai maksimum sebesar 0.13 diperoleh perusahaan Centratama Telekomunikasi Indonesia Tbk. Rata-rata abnormal return H-3 bernilai negatif sebesar -0.0054 dan standar deviasi sebesar 0.05068 .

Pada H-2 nilai minimum sebesar -0.25 diperoleh perusahaan Marga Abhinaya Abadi Tbk. Nilai maksimum sebesar 0.13 diperoleh perusahaan Bank Maspion Indonesia Tbk. Rata-rata abnormal return $\mathrm{H}-2$ bernilai negatif sebesar 0.0080 dan standar deviasi sebesar 0.05124. Pada H-1 nilai minimum sebesar 0.13 diperoleh perusahaan Marga Abhinaya Abadi Tbk. Nilai maksimum sebesar 0.36 diperoleh perusahaan Anugerah Kagum Karya Utama Tbk. Rata-rata abnormal return H-1 bernilai positif sebesar 0.0035 dan standar deviasi sebesar 0.05888. Pada hari $\mathrm{H}$ nilai minimum sebesar -0.08 diperoleh perusahaan HM Sampoerna Tbk. Nilai maksimum sebesar 0.32 diperoleh perusahaan Anugerah Kagum Karya Utama Tbk. Rata-rata abnormal return hari $\mathrm{H}$ bernilai positif sebesar .0081 dan standar deviasi sebesar 0.06787 .

Pada $\mathrm{H}+1$ nilai minimum sebesar -0.12 diperoleh perusahaan Bank Windu Kentjana International Tbk. Nilai maksimum sebesar 0.38 diperoleh perusahaan Anugerah Kagum Karya Utama Tbk. Rata-rata abnormal return $\mathrm{H}+1$ bernilai positif sebesar 0.0116 dan standar deviasi sebesar 0.07208. Pada H+2 nilai 
John Santo dan Henny Rahyuda, Reaksi Pasar Terhadap ...

minimum sebesar -0.17 diperoleh perusahaan Centratama Telekomunikasi Indonesia Tbk. Nilai maksimum sebesar 0.24 diperoleh perusahaan AirAsia Indonesia Tbk. Rata-rata abnormal return $\mathrm{H}+2$ bernilai negatif sebesar -0.0060 dan standar deviasi sebesar 0.06368 . Pada $\mathrm{H}+3$ nilai minimum sebesar -0.13 diperoleh perusahaan Sekar Bumi Tbk. Nilai maksimum sebesar 0.24 diperoleh perusahaan AirAsia Indonesia Tbk. Rata-rata abnormal return $\mathrm{H}+3$ bernilai negatif sebesar -0.0086 dan standar deviasi sebesar 0.04245 . Pada $\mathrm{H}+4$ nilai minimum sebesar -0.14 diperoleh perusahaan Red Planet Indonesia Tbk. Nilai maksimum sebesar 0.09 diperoleh perusahaan Bank Maspion Indonesia Tbk. Rata-rata abnormal return $\mathrm{H}+4$ bernilai negatif sebesar -0.0086 dan standar deviasi sebesar 0.04079. Pada H+5 nilai minimum sebesar -0.10 diperoleh perusahaan Anugerah Kagum Karya Utama Tbk. Nilai maksimum sebesar 0.21 diperoleh perusahaan Rimo Internasional Lestari Tbk. Rata-rata abnormal return $\mathrm{H}+5$ bernilai positif sebesar 0.0039 dan standar deviasi sebesar 0.03683 .

Selanjutnya dilakukan pengujian normalitas dengan menggunakan Kolmogorov-Smirnov untuk mengetahui variabel berdistribusi normal atau tidak. Uji normalitas hanya dilakukan pada sebelum dan sesudah right issue karena ingin melihat perbedaan abnormal return antara sebelum dan sesudah right issue.

Tabel 2.

Hasil Uji Normalitas

\begin{tabular}{lll}
\hline & Sebelum & Sesudah \\
Right Issue & Right Issue \\
\hline
\end{tabular}
.016 .000 
Berdasarkan Tabel 2 menunjukkan bahwa asymp. Sig (2-Tailed) $<0.05$ berarti data berdistribusi tidak normal. Data akan diuji dengan metodologi statisik non-parametrik. Alat uji yang digunakan dalam metodologi statistik nonparametrik adalah wilcoxon signed-rank test.

Kemudian pengujian hipotesis untuk melihat adanya abnormal return pada sebelum dan sesudah pengumuman right issue menggunakan alat uji one sample t-test.

Tabel 3.

Hasil Pengujian Abnormal Return pada Sebelum dan Sesudah Pengumuman Right Issue

\begin{tabular}{|c|c|c|c|c|c|}
\hline & & Mean & Std. Deviasi & Sig. (2-tailed) & Keterangan \\
\hline & & .0034 & .05877 & .643 & Tidak Signifikan \\
\hline \multirow[t]{2}{*}{-5} & 6 & & & & \\
\hline & & -.0043 & .05371 & .520 & Tidak Signifikan \\
\hline \multirow[t]{2}{*}{-4} & 6 & & & & \\
\hline & & -.0054 & .05068 & .390 & Tidak Signifikan \\
\hline \multirow[t]{2}{*}{-3} & 6 & & & & \\
\hline & & -.0080 & .05124 & .209 & Tidak Signifikan \\
\hline \multirow[t]{2}{*}{-2} & 6 & & & & \\
\hline & & .0035 & .05888 & .627 & Tidak Signifikan \\
\hline \multirow[t]{2}{*}{-1} & 6 & & & & \\
\hline & & .0116 & .07208 & .197 & Tidak Signifikan \\
\hline \multirow[t]{2}{*}{+1} & 6 & & & & \\
\hline & & -.0060 & .06368 & .445 & Tidak Signifikan \\
\hline \multirow[t]{2}{*}{+2} & 6 & & & & \\
\hline & & -.0086 & .04245 & .103 & Tidak Signifikan \\
\hline \multirow[t]{2}{*}{+3} & 6 & & & & \\
\hline & & -.0086 & .04079 & .092 & Tidak Signifikan \\
\hline \multirow[t]{2}{*}{+4} & 6 & & & & \\
\hline & & .0039 & .03683 & .396 & Tidak Signifikan \\
\hline+5 & 6 & & & & \\
\hline
\end{tabular}


Dari hasil uji one sample t-test terhadap abnormal return dengan tingkat signifikan $\alpha=0.05$. Pada Tabel 3 menunjukkan bahwa pada H-5, H-4, H-3, H-2, $\mathrm{H}-1, \mathrm{H}+1, \mathrm{H}+2, \mathrm{H}+3, \mathrm{H}+4, \mathrm{H}+5$ terdapat sig. (2-tailed) $>0.05$, hal ini berarti bahwa abnormal return yang diperoleh tidak signifikan, dimana tidak signifikan menandakan tidak adanya reaksi pasar sebelum dan sesudah peristiwa right issue. Hal ini mengungkapkan bahwa $\mathrm{H}_{1}$ ditolak bahwa tidak terjadi abnormal retun sebelum dan sesudah pengumuman right issue.

Pengujian hipotesis untuk melihat adanya abnormal return pada saat pengumuman right issue dilakukan dengan menggunakan alat uji one sample ttest.

Tabel 4.

Hasil Pengujian Abnormal Return pada Saat Pengumuman Right Issue

\begin{tabular}{|c|c|c|c|c|}
\hline $\mathrm{N}$ & $\begin{array}{l}\text { Rata-rata } \\
\text { Abnormal } \\
\text { Return }\end{array}$ & Std. Deviasi & Sig. (2-tailed) & Keterangan \\
\hline 66 & .0081 & .06787 & .339 & Tidak Signifikan \\
\hline
\end{tabular}

Dari hasil uji one sample t-test terhadap abnormal return dengan tingkat signifikan $\alpha=0.05$. Pada Tabel 4 menunjukkan bahwa pada saat hari $H$ pengumuman right issue, terdapat sig. (2-tailed) $>0.05$, hal ini berarti bahwa abnormal return yang diperoleh tidak signifikan, dimana tidak signifikan menandakan tidak adanya reaksi pasar pada saat peristiwa right issue. Hal ini mengungkapkan bahwa $\mathrm{H}_{2}$ ditolak bahwa tidak terjadi abnormal retun pada saat pengumuman right issue. 
Pengujian hipotesis untuk mengetahui perbedaan abnormal return sebelum dan sesudah peristiwa right issue dilakukan dengan metodologi statistik nonparametrik wilcoxon signed-rank test dibantu oleh program SPSS.

\section{Tabel 5.}

Hasil Pengujian Perbedaan Abnormal Return Sebelum dan Sesudah Pengumuman Right Issue

\begin{tabular}{lr}
\hline & \multicolumn{2}{c}{$\begin{array}{c}\text { Sesudah Right Issue - Sebelum } \\
\text { Right Issue }\end{array}$} \\
\hline $\mathrm{Z}$ & $-1.153^{\mathrm{b}}$ \\
Asymp. Sig. (2-tailed) & .249 \\
\hline
\end{tabular}

Sumber: Data diolah, 2018

Pada Tabel 5 menjelaskan hasil uji dengan wilcoxon signed-rank test, menghasilkan sig. (2-tailed) $>0.05$ sebesar 0.249. Hal ini mengungkapkan bahwa $\mathrm{H}_{3}$ ditolak dan menerima $\mathrm{H}_{0}$ yaitu tidak terdapat perbedaan abnormal return sebelum dan sesudah pengumuman right issue, karena abnormal return abnormal return yang terjadi tidak mengalami perubahan yang signifikan.

Pengujian hipotesis satu yang dilakukan dengan melihat Tabel 3 menyimpulkan bahwa abnormal return yang diperoleh tidak signifikan. Abnormal return yang tidak signifikan menunjukkan tidak adanya reaksi yang dilakukan oleh investor sebelum dan sesudah pengumuman right issue. Pengumuman right issue tidak mempunyai kandungan informasi yang cukup untuk mempengaruhi preferensi investor dalam pembuatan keputusan investasinya.

Hasil penelitian ini mendukung penelitian sebelumnya yang dilakukan oleh Shahid et al. (2010), Dewi dan Putra (2013), Nurmala dan Salmah (2015) yang menyimpulkan bahwa tidak terjadi abnormal return saham antara periode sebelum dan sesudah pengumuman right issue. 
Pengujian hipotesis dua yang dilakukan dengan melihat Tabel 4 menyimpulkan bahwa pada saat pengumuman right issue tidak terdapat abnormal return yang signifikan. Tidak terdapatnya abnormal return yang signifikan pada saat pengumuman right issue menunjukkan adanya tidak ada reaksi yang dilakukan oleh investor. Hal ini berarti pasar tidak merespon pada saat pengumuman right issue.

Hasil penelitian ini mendukung penelitian sebelumnya yang dilakukan oleh Bharath dan Shankar (2012) dan Bashir (2013) yang menyimpulkan bahwa tidak terjadi abnormal return pada saat pengumuman right issue.

Berdasarkan pengujian hipotesis tiga dengan menggunakan wilcoxon signed-rank test menyimpulkan bahwa tidak terdapat perbedaan abnormal return sebelum dan sesudah peristiwa right issue. Investor menilai adanya corporate action dalam bentuk right issue tidak mampu meningkatkan harga saham perusahaan di masa yang akan datang menyebabkan peristiwa right issue tidak mendapat respon.

Hasil penelitian ini mendukung penelitian yang sudah dilakukan sebelumnya oleh Pratama dan Sudhiarta (2013), Jayanti dan Kristanti (2014), Ardiana dan Susanti (2014), Hermawan dan Wijayanto (2015) yang menyimpulkan bahwa tidak terdapat perbedaan abnormal return saham antara periode sebelum dan sesudah pengumuman right issue.

\section{SIMPULAN DAN SARAN}

Berdasarkan pemaparan diatas dapat disimpulkan beberapa hal sebagai berikut: 1). Tidak terdapat abnormal return yang signifikan sebelum dan sesudah 
pengumuman right issue; 2). Tidak terdapat abnormal return yang signifikan pada saat pengumuman right issu; 3). Tidak terdapat perbedaan abnormal return sebelum dan sesudah pengumuman right issue.

Berdasarkan hasil analisis dan simpulan di atas, maka dapat diajukan beberapa saran yakni bagi perusahaan, pada saat melakukan corporate action dalam hal ini adalah right issue diharapkan melakukan analisis kondisi pasar modal terlebih dahulu. Sehingga dengan adanya right issue, tujuan perusahaan dapat tercapai yakni menghimpun dana dan meningkatkan harga saham. Pasar bereaksi dengan memberikan abnormal return positif. Bagi investor, dalam melakukan aktivitas investasi perlu memperhatikan corporate action yang dilakukan oleh perusahaan. Melakukan peninjauan kembali terhadap kinerja perusahaan yang melakukan pengumuman right issue, sehingga investor mengetahui waktu yang tepat untuk membeli atau menjual sahamnya saat adanya pengumuman right issue dan mendapat keuntungan.

Bagi peneliti selanjutnya, diharapkan dapat melakukan penelitian pada aktivitas corporate action lainnya seperti stock split, saham bonus, pengumuman dividen, merger dan akuisisi untuk melakukan penilaian terhadap harga saham dan melihat bagaimana reaksi yang ditimbulkan.

\section{REFERENSI}

Agarwal, Akshita and Pitabas Mohanty. (2012). The Impact of Right Issue on Stock Return in India. Asia Pacific Finance and Acounting Review Journal, 1 (1), pp.5-16.

Ahkam, Sharif Nurul and Tawfiq Mostafa. (2013). Studying Market Reaction to Right Share Offers in Bangladesh. Proceedings of 3rd Global Acounting, Finance and Economics Conference Rydges Melbourne Australia, 5-7 May 2013. 
Ardiana, Agus dan Putu Adi Susanti. 2014. Reaksi Pasar Terhadap Pengumuman Right Issue pada Perusahaan Warrant Issuer dan Non Warrant Issuer. E-Jurnal Akuntansi Universitas Udayana, 9 (1), hal.221-236.

Bashir, Adnan. (2013). Impact of Right Issue Announcement on Shareholder Wealth: Case Study of Pakistani Listed Companies. International Journal of Contemporary Business Studies, 4 (3), pp.6-12.

Bharath, M., and H. Shankar. (2012). Market Efficiency of Indian Stock Market - A Study of Bonus Announcement in Bombay Stock Exchange. Indian Journal Of Applied Research, 2 (1), pp.45-49.

Cotterell, PJM. (2011). The Impact of Right Issue Announcements on Share Price Performance in South Africa. A Research Project Submitted To The Gordon Institute of Business Science, University of Pretoria, in Partial Fulfillment of The Requirements for The Degree of Master of Business Admnistration. http://upetd.up.ac.za/thesis/available/etd-06242012135803. Diakses pada tanggal 12 Maret 2017.

Dana, Rai Sukmawati dan Komang Ayu Krisnadewi. (2017). Pengaruh Return On Equity dan Leverage pada Saham Bonus di Perusaaan yang Terdaftar di Bursa Efek Indonesia. E-Jurnal Akuntansi Universitas Udayana, 13 (1), hal.265-274.

Dewi, Ni Putu Desy Ratna dan I Made Sukartha. (2015). Reaksi Pasar Terhadap Pengumuman Saham Bonus di Bursa Efek Indonesia. E-Jurnal Akuntansi Universitas Udayana, 10 (1), hal.150-163.

Dewi, Ni Putu Sentia dan I Nyoman Wijana Asmara Putra. (2013). Pengaruh Pengumuman Right Issue pada Abnormal Return dan Volume Perdagangan Saham. E-Jurnal Akuntansi Universitas Udayana, 3 (3), hal.63-178.

Edirisinghe, U. C., and Nimal P. D. (2015). Stock Price Reaction to Announcements of Right Issues and Debenture Issues: Evidence from Colombo Stock Exchange. International Journal of Business and Social Research, 5 (2), pp.67-77

Epriyeni, Ayu dan Rika Kharlina E. (2013). Pengaruh Pengumuman Merger, Akuisisi dan Right Issue Terhadap Abnormal Return Saham di Bursa Efek Indonesia. Jurnal Akuntansi STIE MDP, 1 (3), hal.1-7.

Fahmi, Irham. (2014). Pengantar Manajemen Keuangan. Bandung: Alfabeta.

Hermawan, Tri dan Andhi Wijayanto. (2015). Analisis Perbedaan Abnormal Return, Trading Volume Activity dan Bid Ask Spread Sebelum dan Sesudah 
Pengumuman Right Issue. Management Dynamics Conference UNNES Semarang, 7 Oktober 2015.

Jayanti, Fikka Azelea dan Farida Titik Kristanti. (2014). Analisis Perbedaan Abnormal Return, Volume Perdagangan Saham, dan Variabilitas Tingkat Keuntungan Sebelum dan Sesudah Pengumuman Right Issue. E-Proceding of Management Universitas Telkom, 1 (3), hal.106-121.

Jogiyanto, H.M. (2015). Teori Portofolio dan Analisis Investasi di Pasar Modal, Edisi Kesepuluh. Yogyakarta: BPFE.

Kendirli, Selcuk and Muhammet Emin Elmali. (2016). The Effects of Right Offering Announcements on Returns of Shares of Deposit Banks Traded in Istanbul Stock-Exchange. Journal of Economic Development, Environment and People, 5 (1), pp.1-9.

Khoso, Aijaz Ali, Muhammad Munir Ahmedani, Abdul Subhan Kazi, Muneer Ahmed, and Halar Siddiqui. (2016). The effect of right issue announcement on share prices of companies listed at KSE. International Journal of Multidisciplinary Research and Development, 3 (7), pp.147156.

Kumar, B Rajesh., and Ashok Y.M. (2010). Multiple Events and Wealth Creation In India: An Empirical Analysis. Journal of Managerial Finance, Institute of Public Enterprise India, 6 (1), pp.1-21.

Lianawati, Ni Komang. (2015). Reaksi Pasar Terhadap Peristiwa Right Issue di Bursa Efek Indonesia. E-Jurnal Manajemen Universitas Udayana, 4 (12), hal.4392-4418.

Malhotra, Madhuri., M. Thenmozhi., and Arun Kumar Gopalaswamy. (2012). Liquidity Changes Around Bonus and Rights Issue Announcements: Evidence from Manufacturing and Service Sectors in India. Munich Personal RePEc Archive Journal, 41216, pp.28-33.

Massa, Massimo., Theo Vermalen., and Moqi Xu. (2013). Rights Offerings, Trading, and Regulation: A Global Perspective. Erim Report Series Research In Management Journal Of Economic Literature, pp.1-47.

Miglani, Pooja. 2011. An Empirical Analysis of Impact of Right Issues on Shareholders Returns of Indian Listed Companies. Journal of Arts, Science \& Commerce, 2 (2), pp.169-176.

Nugraha, Ardi dan Rochmawati Daud. (2013). Pengaruh Pengumuman Right Issue Terhadap Tingkat Keuntungan dan Likuiditas Saham Di Bursa Efek 
Indoensia. Jurnal Manajemen dan Bisnis Universitas Sriwijaya, 11 (21), hal.67-82.

Nurmala dan Ninin Non Ayu Salmah. (2015). Reaksi Pasar Terhadap Pengmuman Right Issue di Bursa Efek Indonesia. Jurnal Manajemen dan Bisnis Sriwijaya, 13 (3), hal.332-342.

Otieno, Ouma Duncan and Duncan Elly Ochieng. (2015). The Effect of Right Issue Announcements on Stock Returns for Firms Listed at the Nairobi Securities Exchange. International Journal of Education and Research, 3 (9), pp.411-426.

Pardede, Andi Satia Monang. (2018). Pengaruh Indeks Harga Saham Gabungan, Suku Bunga dan Harga Minyak Dunia Terhadap Nilai Tukar Rupiah Tahun 2012-2016. E-Jurnal Ekonomi Pembangunan Universitas Udayan, 7 (8), hal.1587-1825.

Pratama, I. Gede Surya dan Gede Mertha Sudhiarta. (2013). Analisis Perbandingan Abnormal Return Saham Sebelum dan Sesudah Pengumuman Right Issue. E-Jurnal Akuntansi Universitas Udayana, 3 (3), hal.243-257.

Raja, Mr. Abhay. (2012). Right Issue and Price Behaviour: Indian Evidence, Journal Management Atmiya Institute of Technology and Science, 1 (9), pp.152-154.

Rohit, Babitha., Prakash Pinto, Shakila B. (2016). Impact of Stock Splits and Right Issue Announcements on Market Price: Evidence From India. Drishtikon: A Management Journal, 7 (2), pp.1-16.

Shahid, Humera., Xia Xinping., Faiq Mahmood., and Muhammad Usman. 2010. Announcement Effects of Seasoned Equity Offerings in China. International Journal of Economics and Finance, 2 (3), pp.163-169.

Sugiyono. (2012). Metode Penelitian Kuantitatif Kualitatif dan R\&D. Bandung: Alfabeta.

Suresha, B., and Gajendra Naidu. (2012). An Empirical Study on Announcement Effect of Right Issue on Share Price Volatility and Liquidity and Its Impact on Market Wealth Creation of Informed Investor in Bangalore with Special Reference to CNX Nifty Stock of NSE. EXCEL International Journal of Multidisciplinary Management Studies, 2 (7), pp.41-58.

Sutedi, Adrian. (2012). Produk-Produk Derivatif dan Aspek Hukumnya. Bandung: Alfabeta. 
E-Jurnal Manajemen, Vol. 8, No. 4, 2019: 1985 - 2013

Swari, Ayu Winda dan Bagus Wiksuana. (2015). Analisis Kinerja Saham Sebelum Dan Sesudah Stock Split Pada Perusahaan Yang Terdaftar Di Bursa Efek Indonesia. E-Jurnal Manajemen Universitas Udayana, 4 (1), hal.275-289.

Tandelilin, Eduardus. (2010). Portofolio dan Investasi: Teori dan Aplikasi, Edisi Pertama. Yogyakarta: Kanisius.

Wistawan, I Made Andika Pradnyana dan A.A.G.P. Widanaputra. (2013). Dampak Pengumuman Pemecahan Saham pada Perbedaan Abnormal Return. E-Jurnal Akuntansi Universitas Udayana, 5 (1), hal.1-16. 